\title{
A land cover map of South America
}

\author{
HUGH D. EVA*, ALAN S. BELWARD*, EVARISTO E. DE MIRANDA†, CARLOS M. DI

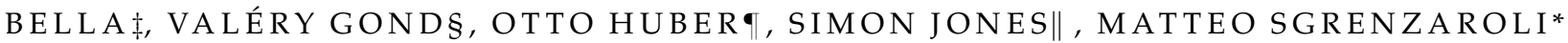 \\ and STEFFEN FRITZ* \\ *Institute for Environment and Sustainability (IES), TP 440, Joint Research Centre of the European Commission, Ispra I-21020, \\ Italy, †Empresa Brasileira de Pesquisa Agropecuária (EMBRAPA-CNPM), Av. Dr Julio Soares de Arruda, 803, CEP 13088-300, \\ Campinas/SP, Brazil, łInstituto de Clima y Agua (INTA), Los Reseros y Las Cabañas S/N (1712), Castelar, Buenos Aires, \\ Argentina, §CIRAD/UMR - ECOFOG, Route de Montabo, BP 165, 97323, Cayenne, French Guyana, - CoroLab Humboldt, IVIC, \\ Caracas, Venezuela, ||School of Mathematical and Geospatial Sciences, RMIT University, Melbourne, Australia
}

\begin{abstract}
A digital land cover map of South America has been produced using remotely sensed satellite data acquired between 1995 and the year 2000. The mapping scale is defined by the $1 \mathrm{~km}$ spatial resolution of the map grid-cell. In order to realize the product, different sources of satellite data were used, each source providing either a particular parameter of land cover characteristic required by the legend, or mapping a particular land cover class. The map legend is designed both to fit requirements for regional climate modelling and for studies on land cover change. The legend is also compatible with a wider, global, land cover mapping exercise, which seeks to characterize the world's land surface for the year 2000. As a first step, the humid forest domain has been validated using a sample of high-resolution satellite images. The map demonstrates both the major incursions of agriculture into the remaining forest domains and the extensive areas of agriculture, which now dominate South America's grasslands.
\end{abstract}

Keywords: Amazonia, ecosystems, land cover, mapping, South America, vegetation classes

Received 2 November 2002; revised version received 19 February 2003 and accepted 1 April 2003

\section{Introduction}

The distribution of natural vegetation is largely determined by climate and the vegetation cover itself plays an important role in the climate system by influencing energy, water and gas exchanges with the atmosphere, and by acting as a source and sink in biogeochemical cycles (Sellers et al., 1997). The dynamic equilibrium that exists between regional climate and vegetation could alter if either component changes (Shukla et al., 1990). In South America, perturbations in both components are all too apparent.

The strongest natural perturbations in South America's climate result from the El Niño Southern Oscillation (ENSO) events. ENSO events are associated with dry anomalous conditions in northern Amazonia and northeast Brazil (Marengo, 1992). These droughts are associated with increased numbers of forest fires. Recent evidence from satellite observations of rainfall shows that the smoke from fires further reduces rainfall

Correspondence: Hugh Eva, tel. + 39033278 5110, fax + 39033278 9073, e-mail: hugh.eva@jrc.it because the emissions saturate the atmosphere with condensation nuclei, thus shutting down the warm rain processes in convective tropical clouds (Rosenfeld, 1999). Many of the continent's dryland ecosystems are already subject to desertification (UNEP, 1999), grassland production could be reduced because of increasingly variable precipitation if ENSO events become stronger and more frequent. Likewise agricultural activities in specific parts of the continent may change in response to climatic shifts. Northeast Brazil's production could decline and adaptation strategies such as increasing irrigation and increasing fertilization would be required (Rosenzweig \& Hillel, 1998).

Anthropogenic land cover change is most evident in the processes of deforestation and agricultural expansion. The UN Population Division puts the year 2000 population for Latin America and the Caribbean at 519 million and predicts this could rise to as many as 1025 million by 2050 (United Nations, 2001). To provide for the growing population the forests will very likely continue to be cleared to make way for agriculture, ranching and plantations. Commercial wood harvesting also is likely to increase. Latin America's humid 
tropical forests declined by 16 million hectares between 1990 and 1997, an average rate of $0.38 \%$ per year, though annual deforestation rates in hot-spots reached over 4\% (Achard et al., 2002). This replacement of forest with agriculture or pasture reduces water cycling and could lead to reduced rainfall (Nobre et al., 1991).

The large-scale biosphere-atmosphere (LBA) experiment in Amazonia aims to determine how changes in land use and climate affect the biological, chemical and physical functions of Amazonia, including the sustainability of development in the region and the influence of Amazonia on global climate, and determine how Amazonia currently functions as a regional entity. Reliable baseline information concerning the continent's land cover is essential to determine likely climate change scenarios, model the impacts of climate change, plan for sustainable development and protect the continent's biodiversity.

A number of land cover databases are available for South America, but they all have some drawbacks for use in climate and sustainable-development research as envisioned by LBA. The maps from the 1970s and 1980s, which were assembled from data from diverse sources, all include a climate component in the classification scheme. They therefore represent an inseparable mix of actual and potential land cover, and all describe conditions as they were 20-30 years ago (Holdridge et al., 1971; Hueck \& Seibert, 1972; UNESCO, 1981). More recently, Harcourt \& Sayer (1996) collated information from national sources to produce a continental forest cover database though the diverse primary data sources used limit the internal consistency of this database. More consistent maps have been obtained by using data from meteorological Earth Observing satellites acquired between 1992 and 1993 for the land cover mapping efforts of the International Geosphere Biosphere Programme (IGBP) (Stone et al., 1994; Loveland et al., 1999). The IGBP classification scheme is also being used to generate new land cover maps using current observations from sensors on the Terra-1 satellite (Friedl et al., 2002).

This paper describes a new database, which should provide scientists with better tools to model climate change and to monitor land cover dynamics. The map legend, classification methods, the accuracy assessment process, the area and the percentage land cover for major cover types and the resulting map are all presented.

\section{Defining a new land cover legend}

The definition of the legend was driven by the need to partition land cover in biogeophysical terms, whilst retaining information on key South American ecosys- tems. To provide adequate land surface parameterization for models, evergreen and deciduous canopy types were separated as were perennial and annual aboveground biomass. The resulting classes can be used for carbon cycle dynamics studies, and as a means of defining seasonal/regional variations in surface albedo, surface moisture availability and aerodynamic roughness length; the classification also separated needle leaf, broadleaf and grasses as gas exchange characteristics are affected by leaf type (Dorman \& Sellers, 1989). Further separation of land cover types was then needed to adequately document processes such as agricultural expansion. Converting non-agricultural land (predominantly forest in Amazonia) to cropland or pasture has a dramatic impact on biogeochemical cycles and associated non-climatic global changes including ecosystem simplification and species extinction (Tilman et al., 2001). Thus, areas of intensive agriculture and areas where agriculture is mixed with non-forest or forest cover types were separated. Similar attention was paid to environmentally sensitive South American ecosystems such as wetlands and seasonally flooded grasslands. This scheme results in 39 classes identified on the basis of land cover type, seasonality, vegetation cover and water regime. Furthermore, we added altitudinal divisions for the forest classes, as climate change in cloud forests has been shown to have an important impact (Pounds et al., 1999). The classes are then grouped on the basis of vegetation structural categories (Eiten, 1968), which gives 10 broad class divisions at the first level. At this first level the classes are broadly grouped as; forests, shrublands, grasslands, barren surfaces, water, ice and snow. Subsequently, we introduce canopy structure (open/closed), vegetation cover (dense/sparse), seasonality, flooding regime, climate and altitude. Details of the classes are provided in Table 1.

The South America map has been produced as part of a project to map Global Land Cover for the year 2000 'GLC 2000' (Bartholomé et al., 2002a) along with a global burnt area product-'GBA 2000' (Grégoire et al., 2003). The classes in Table 1 have also all been classified according to the UN Food and Agriculture Organization's Land Cover Classification System (LCCS) so that they can be integrated into the Global Land Cover database. This database has been developed to analyse and cross-reference regional differences in land cover descriptions (Di Gregorio \& Jansen, 2000). It describes land cover according to a hierarchical series of classifiers and attributes that separate vegetated or non-vegetated surfaces, terrestrial or aquatic/flooded, cultivated and managed, natural and semi-natural, life-form, cover, height, spatial distribution, leaf type and phenology. 
Table 1 The distribution of land cover classes across South America (rounded to $100 \mathrm{~km}^{2}$ ) altitudinal thresholds of 500 and $1000 \mathrm{~m}$ are used to give the distribution of forests into lowland (L), premontane $(\mathrm{P})$ and montane $(\mathrm{M})$ classes

\begin{tabular}{|c|c|c|c|c|c|c|c|}
\hline \multirow[b]{2}{*}{ Level 1} & \multirow{2}{*}{$\begin{array}{l}\text { Land cover class } \\
\text { Level } 2\end{array}$} & \multirow[b]{2}{*}{ Level 3} & \multicolumn{3}{|c|}{$\begin{array}{l}\text { Forest altitudinal } \\
\text { distribution }(\%)\end{array}$} & \multirow{2}{*}{$\begin{array}{l}\text { Surface } \\
\text { area }\left(\mathrm{km}^{2}\right)\end{array}$} & \multirow[b]{2}{*}{ Percentage } \\
\hline & & & $\mathrm{L}$ & $\mathrm{P}$ & M & & \\
\hline \multirow[t]{3}{*}{ Humid tropical forests } & Evergreen broadleaf & Closed/open & 89.0 & 6.1 & 4.9 & 6143000 & 34.55 \\
\hline & Evergreen broadleaf & Bamboo dominated & 92.1 & 7.9 & 0.0 & 75500 & 0.42 \\
\hline & Semi-humid broadleaf & Closed/open & 85.5 & 14.4 & 0.1 & 86800 & 0.49 \\
\hline \multirow[t]{3}{*}{ Dry tropical forests } & Deciduous forests & Closed/open & 75.9 & 18.4 & 5.6 & 1115700 & 6.28 \\
\hline & Semi-deciduous forest & Closed/open & 34.9 & 12.0 & 53.2 & 142100 & 0.80 \\
\hline & Semi deciduous transition forest & & 100.0 & - & - & 209400 & 1.18 \\
\hline \multirow{3}{*}{$\begin{array}{l}\text { Flooded tropical } \\
\text { forests }\end{array}$} & Coastal flooded forests - mangroves & & 100.0 & - & - & 17300 & 0.10 \\
\hline & Fresh water flooded forests & & 100.0 & - & - & 199300 & 1.12 \\
\hline & Swamp forests - open with palms & & 100.0 & - & - & 53900 & 0.30 \\
\hline \multirow[t]{3}{*}{ Temperate forests } & Evergreen broadleaf & Closed/open & 56.5 & 25.9 & 17.6 & 61700 & 0.35 \\
\hline & $\begin{array}{l}\text { Evergreen mixed broad and } \\
\text { needle leaf }\end{array}$ & & 42.7 & 36.6 & 20.7 & 29600 & 0.17 \\
\hline & Deciduous forests & Closed/open & 58.1 & 20.2 & 21.7 & 105500 & 0.59 \\
\hline \multirow[t]{4}{*}{ Agriculture } & Intensive & & & & & 2024700 & 11.39 \\
\hline & $\begin{array}{l}\text { Mosaic of degraded } \\
\text { non-forest vegetation }\end{array}$ & & & & & 735300 & 4.14 \\
\hline & $\begin{array}{l}\text { Mosaic of degraded } \\
\text { forest vegetation }\end{array}$ & & & & & 1513600 & 8.51 \\
\hline & Forest plantations & & & & & 3400 & 0.02 \\
\hline \multirow{7}{*}{$\begin{array}{l}\text { Grass and } \\
\text { shrub lands }\end{array}$} & Savannah & & & & & 350900 & 1.97 \\
\hline & Shrub savannah & & & & & 738400 & 4.15 \\
\hline & Flooded savannah & & & & & 320900 & 1.81 \\
\hline & Shrublands & & & & & 1412900 & 7.95 \\
\hline & Flooded shrublands & & & & & 13000 & 0.07 \\
\hline & Moorlands/heath & & & & & 106900 & 0.60 \\
\hline & Montane grasslands & Closed/open & & & & 280300 & 1.58 \\
\hline \multirow[t]{2}{*}{ Steppe vegetation } & Grasslands & Closed/open & & & & 666100 & 3.75 \\
\hline & Sparse shrubland & & & & & 566700 & 3.19 \\
\hline \multirow{3}{*}{$\begin{array}{l}\text { Little or sparse } \\
\text { vegetation }\end{array}$} & Bare soil/barren & & & & & 346000 & 1.95 \\
\hline & Desert & & & & & 194500 & 1.09 \\
\hline & Salt pans & & & & & 9400 & 0.05 \\
\hline \multirow[t]{2}{*}{ Water bodies } & $\begin{array}{l}\text { Natural and artificial } \\
\text { water bodies }\end{array}$ & & & & & 220200 & 1.24 \\
\hline & Permanent ice and snow & & & & & 23900 & 0.13 \\
\hline Urban & $\begin{array}{l}\text { Urban and other man-made } \\
\text { surfaces }\end{array}$ & & & & & 11400 & 0.06 \\
\hline Total & & & & & & 17778300 & 100.00 \\
\hline
\end{tabular}

\section{Materials and methods}

To meet the requirements of the legend, a number of different sources of remotely sensed satellite data were used. Each of these data sets has its own potential application and contributes to mapping a specific ecosystem or land cover, seasonality or water regime. This approach to mapping is in contrast to previous continental maps, which have been derived from single-source data. A total of 1600 satellite images were used in the preparation of the map, comprising of $400 \mathrm{~Gb}$ of raw data.
Low spatial resolution satellite data acquisition and preprecessing

Three types of low spatial resolution satellite data are used: Along Track Scanning Radiometer (ATSR-2); SPOT VEGETATION (VGT) and The Defense Meteorological Satellite Program (DMSP) Operational Linescan System (OLS). These data were used to map evergreen forest formations, unvegetated and seasonal formations, and urban areas, respectively. The ATSR-2 is on board the ERS-2 satellite. The sensor acquires data in a $500 \mathrm{~km}$ swath at nominal $1 \mathrm{~km}$ spatial resolution, 
available in visible (green and red), near infra-red (NIR), short-wave infra-red (SWIR) and thermal bands (TIR). The SWIR and thermal bands allow good discrimination between dense humid forests and seasonal forest formation and non-forests. The SWIR is highly sensitive to vegetation moisture content (Guyot et al., 1985) and, as a result of high evapotranspiration, the humid forests remain cooler than other land cover types and hence give a lower thermal signature. The fine spectral bandwidths allow for the detection of some specific humid forest types, notably mangroves and bamboo dominated areas. Between 1999 and 2001 over 1000 ATSR images of Latin America were acquired in near-real-time through the European Space Agency's world wide web server. The ATSR data were corrected to top of atmosphere reflectance by applying the calibration tables provided by the sensor designers, Rutherford Appleton Laboratories (http:// www.atsr.rl.ac.uk/). The data were composited together into a continental mosaic by selecting pixels with the highest surface temperature. This type of composite avoids a number of well-documented artefacts associated with compositing techniques (Cihlar et al., 1994) as well as masking out both cloud and edge of cloud, which are frequently present over the Amazon basin. The temperature of contiguous blocks of forests tends to be homogenous. As a result, the speckled effect found on many composites due to the selection of pixels from different image dates is reduced. This selection process is, however, rarely used as it produces mosaics from the tropical dry season, where seasonal forests are difficult to discriminate from other nonforest formations due to the loss of foliage. At the same time, in savannah ecosystems, it selects burnt areas (Eva \& Lambin, 1998). In our case, this serves our purposes in that it gives a mosaic, in which evergreen forest formations are clearly delineated from bare soil and from seasonal vegetation formations. Only the red, NIR and SWIR channels are retained for the mosaic. The green channel is rejected as it is easily contaminated by haze, and the thermal channel is also rejected as its low variance over a scene reduces class separation any multi-spectral classification process.

The SPOT VGT sensor onboard the SPOT 4 satellite is similarly a $1 \mathrm{~km}$ resolution sensor. It is one of the first sensors to be specifically designed for global vegetation monitoring. It has a $2000 \mathrm{~km}$ swath enabling daily acquisition of data even at the equator. It samples data in the visible (blue and red), near and short-wave infrared, but has no thermal imaging capacities. The daily availability of data makes the VGT instrument invaluable in monitoring the seasonality of vegetation formations, especially in tropical areas, where cloud-free data are difficult to acquire. The VGT data were provided in single-day (S1) and 10-day composites (S10) consisting of the four spectral channels, and the vegetation index - NDVI (normalized difference vegetation index). The S1 data were used for producing a number of byproducts (cloud cover and vegetation fractional cover). The S10 data were themselves composited into four mosaics: boreal winter (data from December 1999 to February 2000); spring (March 2000 to May 2000); summer (June 2000 to August 2000) and autumn (September 2000 to November 2000). The selection process took the pixel from the image with the lowest short-wave value after cloud screening. This technique is known to produce cloud shadow artefacts. These are avoided by the application of a buffer around the cloud. For the resulting mosaic, the red, NIR and SWIR channels were retained. The blue channel, being sensitive to atmospheric contamination, was rejected. At the same time vegetation index (NDVI) profiles were synthesized using the highest value into monthly products so as to provide information on the duration and magnitude of the vegetation growing season and maximum vegetation ground cover. A comparison of the NDVI with the bare soil NDVI gives us a measure of the fractional green cover (Gutman \& Ignatov, 1998), and has been adapted for use with the VGT sensor (Bartholomé et al., 2002b). To reduce cloud contamination a spline smoothing (Van Dijk et al., 1987) has been applied to the data on a pixel basis.

Whilst urban areas can often be visually detected on low-resolution satellite images, due to their context and location, they are problematic to extract from the digital data. This arises because their spectral signature is similar to bare soil. To overcome this problem we used radiance calibrated lights data from the DMSP to locate the major urban areas. The DMSP OLS sensor has two spectral bands (visible and thermal infra-red) and a swath width of around $3000 \mathrm{~km}$. The OLS has low light sensing capabilities, which go down to $10-9 \mathrm{~W}$ $\mathrm{cm}^{-2} \mathrm{sr}^{-1} \mu \mathrm{m}^{-1}$ at night. By monitoring the frequency of light sources, the location of human settlements can be determined (Elvidge et al., 1997) so-called 'stable lights'.

\section{Medium spatial resolution radar data}

Seasonally and permanently flooded forests are an important land cover class in the humid rainforests of South America. Low-resolution optical data are unsuitable for the detection and mapping of such classes, as the forest canopy usually obscures the water from the satellite's field of view. For this reason radar data were acquired from the Global Rain Forest Mapping project (GRFM, Rosenqvist et al., 1996) The data, from the JERS-1 L band radar, are available as full mosaics covering the humid forests, geometrically corrected at a 
Table 2 Sources of information for delineating vegetation

\begin{tabular}{|c|c|}
\hline Biome & Source \\
\hline Tropical rain forests & $\begin{array}{l}\text { Oliveira \& Nelson (2001), Ducke \& Black (1953), De Granville (1988), Gentry }(1990,1995), \text { Pires \& } \\
\text { Prance (1985), Clark \& Clark (2000), Berry et al. (1995) }\end{array}$ \\
\hline Tropical dry forests & $\begin{array}{l}\text { Bullock et al.(1995), Parker et al. (1993), Bucher (1982), Sampaio (1995), Adamoli et al. (1990), } \\
\text { Spichiger \& Ramella, (1988) }\end{array}$ \\
\hline Flooded forests/mangroves & Adis (1984), Junk (1989), Lescure \& Tostain, (1989), Pires \& Prance (1985) \\
\hline Montane forests & Haber et al. (2000), Stadtmüller (1987), Cavelier \& Etter (1995) \\
\hline Montane grasslands & Balslev \& Luteyn (1992) \\
\hline Shrublands & Huber (1988b), Berry et al. (1995), León, et al. (1998), Paruelo et al. (1998) APN (1999) \\
\hline Tropical grasslands & $\begin{array}{l}\text { Huber et al. (2001), Berry et al. (1995), Sarmiento (1984), Ratter (1992), Barbosa (1996), Eiten (1982), } \\
\text { Pires \& Prance (1985) }\end{array}$ \\
\hline Temperate grasslands & Guerschman et al. (2003), Soriano (1993), León, et al. (1998), Paruelo et al. (1998), APN (1999) \\
\hline Temperate forest & $\begin{array}{l}\text { Armesto et al. (1998), Veblen et al. (1996), CI (1992), Neira et al. (2002), León, et al. (1998), Paruelo } \\
\text { et al. (1998), APN (1999) }\end{array}$ \\
\hline
\end{tabular}

nominal $100 \mathrm{~m}$ resolution pixel with backscatter scaled to 8 bits. Two mosaics were produced covering South America's tropical forests, one the high water mosaic, coinciding with the high water period of the Amazon river at Manaus (May-July 1996) and the other, the low water mosaic, produced from data (September-December 1995) to coincide with the low water period. The radar signal penetrates the forest canopy and is amplified by the presence of water under the forest canopy, in an effect called double bounce. Thus an intercomparison of the two mosaics gives an indication of areas of the major regions of flooded forests (Rosenqvist et al., 1998).

\section{Ancillary data}

Forest and land cover maps were assembled to aid in the labelling of spectral classes. These cover the majority of the land surface of South America, from continental maps (Holdridge et al., 1971; Hueck \& Seibert, 1972; UNESCO, 1981) to country maps of Argentina (APN, 1999), Bolivia (MDSMA, 1995), Brazil (IBGE, 1995; RADAMBRAZIL, 1973-1978), Chile (Neira et al., 2002), Colombia (IGAC, 1987), Guyana (Huber et al., 1995; ter Steege, 2001) Ecuador (Sierra, 1999), Peru (INRENA, 1996) and Venezuela (Huber \& Alarcón, 1988; Huber, 1995).

In addition to this, maps and information on the spatial distribution and characteristics of ecosystems were collected from the literature (Table 2).

Altitude thresholds for the montane forests were applied using the US Geological Survey's 'GTOPO30' (Bliss \& Olsen, 1996). A systematic review of national topographic maps revealed this to be valid at the continental scale with the exception of the Venezuelan Guayana, where the data were amended according to the topographic map of the region provided by Berry et al. (1995). Forest classes were divided into lowland (less than $500 \mathrm{~m}$ asl) premontane $(500-1000 \mathrm{~m}$ asl) and montane ( $>1000 \mathrm{~m}$ asl) forests.

\section{Image classification techniques}

The low resolution optical ATSR and VGT data were used to spatially identify and isolate regions exhibiting similar spectral responses to solar radiation in a range of wavelengths, and their variation throughout the year. The two mosaics were independently classified using the unsupervised clustering algorithm, ISODATA (Ball \& Hall, 1965). This approach was used as it requires little a priori knowledge and as suitable training data is difficult to apply at continental levels (i.e. for a supervised maximum likelihood classifier).

The subsequent classes were labelled on the basis of visual interpretation of the satellite data with the resulting classification. In this technique each individual spectral class is independently overlaid on the satellite imagery. An analyst, working to a defined legend, supported by vegetation dynamics statistics derived from the remote sensing data and by regional maps and literature, then assigns the class to a particular land cover type. In this way the thematic legend is taken from existing reference material, while the spatial extent and location, along with supporting evidence on vegetation cover and seasonality, is provided by the remote sensing data. This approach to exploiting low spatial resolution satellite data has been successfully demonstrated by D'Souza et al. (1995), Eva et al. (1999), Stone et al. (1994), Mayaux et al. (1997) and Achard \& Estreguil (1995).

\section{Evergreen forests}

The spectral clustering was applied firstly to the ATSR mosaic. Visual analysis of the spectral classes resulted 
in, first, separating the classes into evergreen forest types and non-evergreen forest types. Subsequently, within the evergreen forest classes, two classes showed distinct spatial and spectral characteristics that enabled them to be identified from existing ancillary material as specific forest formations - bamboo-dominated forests and mangroves.

\section{Other vegetation formations}

A similar approach was used to derive the seasonal classes derived from SPOT VGT data. The four seasonal mosaics were combined into one data file. Those classes already identified by the ATSR data as evergreen forest were masked out from the new SPOT mosaic. This was done to reduce both the size of the data set and possible class confusion in the SPOT data. The remaining area, 'non-evergreen forest', was classified by the same procedure using ISODATA to produce 80 spectral classes. The SPOT NDVI data set was then used to extract the NDVI profile for each class produced by ISODATA. The interpretation of these classes was again undertaken by visual examination in conjunction with the examination of the monthly NDVI profiles to determine the percentage vegetation cover and the length of growing season. In Fig. 1 we show the NDVI derived profiles for example classes. These profiles help to determine the class labels of seasonality and vegetation cover (Fig. 2).

\section{Flooded forests}

For the flooded forest detection, a local statistical filter (30 by 30 pixels) was used to calculate the variance of the radar backscatter in the low water JERS mosaic. Those pixels on the high water mosaic, which were found to have a backscatter more than 2 standard deviations higher than the equivalent low water mosaic pixel, were classed as potential flooded forests. Visual interpretation was required to set an appropriate threshold to discriminate the areas of flooding and exceptional signal fluctuation, which was seen to occur in two or three of the radar scenes, which made up the mosaic and on the topography of the Guayana highlands. The resultant layer was merged with the forest layer obtained from the ATSR data, to give a seasonally flooded forest layer.

\section{Urban areas}

The DMSP data were overlaid on the SPOT VGT mosaic to ensure adequate colocation. Major South American cites were used, and no significant misalignment was evident. However, it was apparent that DMSP calibrated lights data tend to overestimate the urban extent due to the scattering of light in the atmosphere, as noted by Elvidge et al. (1999). Therefore the data sets have been used as a 'seeding' layer to locate the presence of large urban areas in the SPOT VGT data. A mask was created from the DMSP data to extract from the SPOT data only the areas under the DMSP light signal. This much-reduced data set was then classified using ISODATA into 10 thematic classes. The classification was then overlaid on the SPOT VGT mosaic to determine by visual interpretation which of the 10 classes were related to pure urban areas. It was found that three of the classes could be identified as urban while the rest resulted from the spread of light.

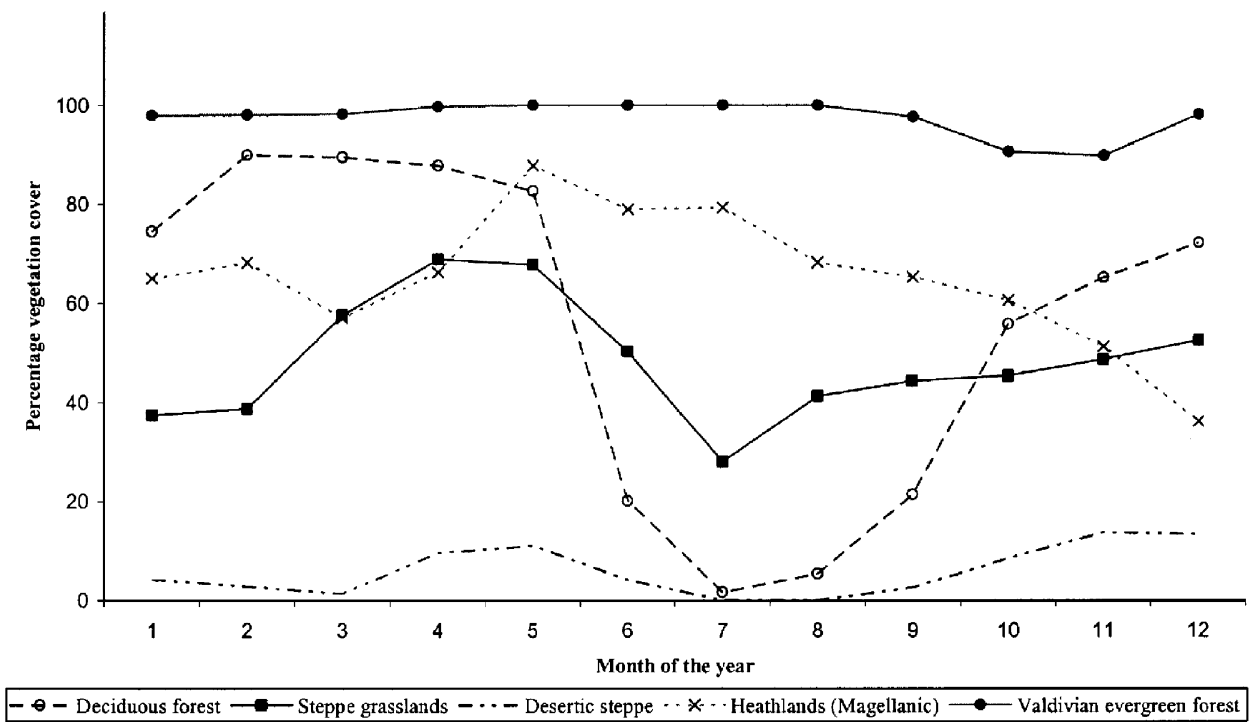

Fig. 1 A plot of green vegetation cover variation during the year for different cover types. From these plots we area able to deduce cover and seasonality. 


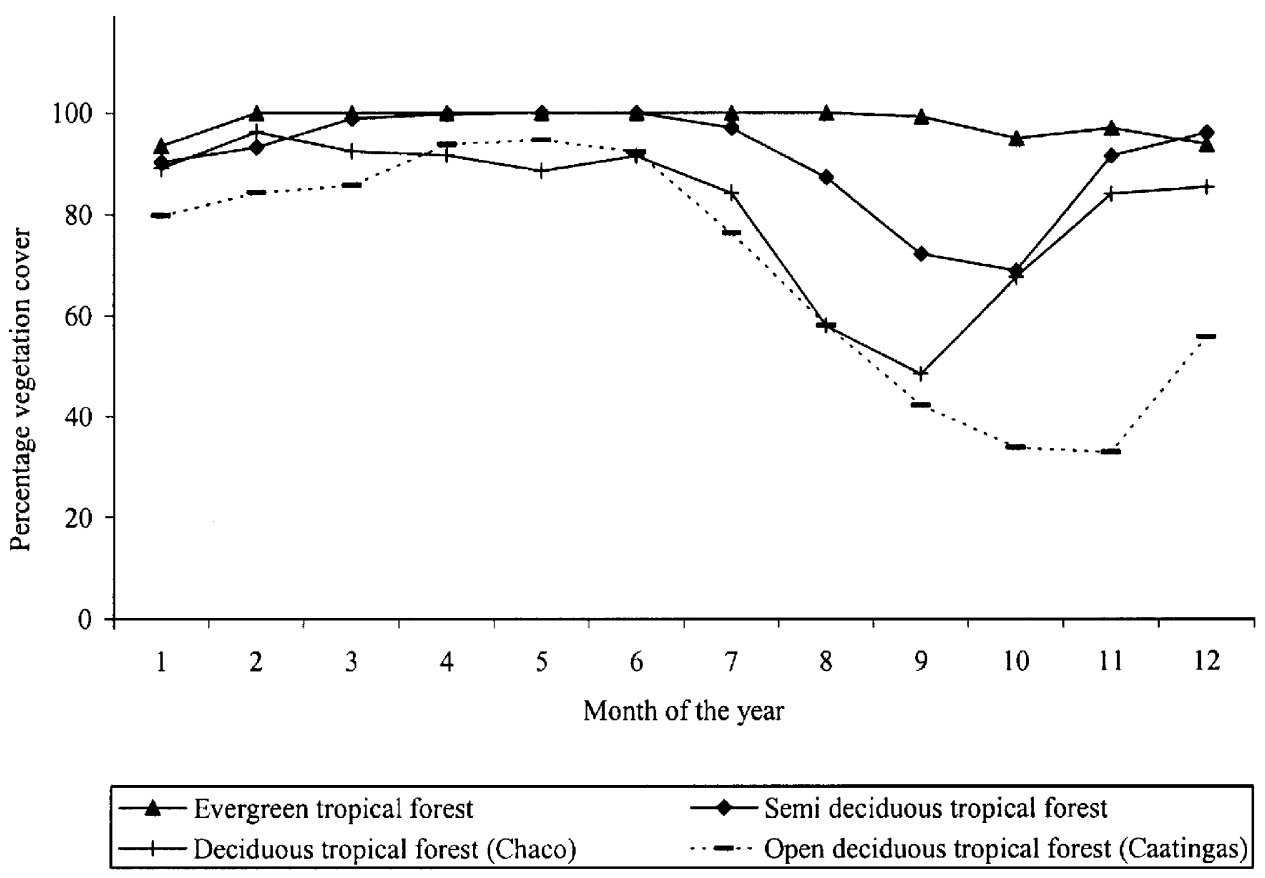

Fig. 2 The differences in seasonality and green vegetation cover for four types of neotropical forest.

\section{Validation data}

Spatial and thematic validation of continental land cover maps present many problems due to both the large areas concerned, the diverse ecosystems and to the lack of homogeneous national legends and, not least, the potential financial costs of such exercises. To validate the DISCover global map, the IGBP project aimed at selecting $4151 \mathrm{~km}$ points across the globe for expert interpretation and comparison with the IGBP class (Scepan, 1999). The assessment was carried out on 25 points randomly distributed across the globe for each class. While such a validation exercise gives a measure of reliability at the global level, it does not preclude local mapping errors that can be avoided with a careful expert review of the preliminary product (Fig. 3). Under the GLC 2000 project a two-stage process, to be carried out in 2003, is proposed (Bartholomé et al., 2002a). The first stage is a quality control step, to eliminate macroscopic errors in the spatial delimitation of classes and of class labels. This has been carried out for the South America map using a network of partners across the continent. The second stage consists of a statistical examination of the classes mapped at the global level. A stratified random sample of sites weighted by continent will be selected, with 26 sites per land cover class. The sample sites will consist of subsets of Landsat Thematic Mapper scenes, interpreted by local experts.

For the South America map, we have carried out a preliminary statistical validation using the TREES high-resolution data set (Achard et al., 2002). The advantage of this data set is that it consists of readily available Landsat Thematic Mapper scenes (25 quarter scenes and 15 full scenes) interpreted by regional experts from Brazil, Bolivia, Peru, Venezuela, Colombia and French Guyana. The disadvantages are that (i) the data set is confined to the humid forest domain, (ii) the classification scheme was derived for measuring deforestation, and therefore is less detailed for non-forest classes, (iii) the data are predominantly from 1997 and (iv) in the event of fragmented classes, the differences between the spatial resolution of the reference data and the map data will introduce subpixel classes, which lower the mapping accuracy. It should also be noted that the attributes of both flooding, and seasonality are difficult to assess on single data satellite imagery. As a result we can only claim that our validation data are appropriate for the classes in the humid forest domain. Nevertheless we use 40 Thematic Mapper interpretations (a total area of $498843 \mathrm{~km}^{2}$ ) on one continent as opposed to the $4001 \mathrm{~km}$ sites conducted globally by the IGBP. The high Andine ecosystems, the llanos, the Brazilian catingaas and cerrado, the pampas, steppes and chaco of Argentina, and the Mediterranean and Valdivian ecosystems of Chile, all need to be validated under the GLC 2000 program.

The South America map was remapped to an equal area projection to collocate it with the validation sites. The areas of the major land cover types were extracted from the validation data and the equivalent area on the 

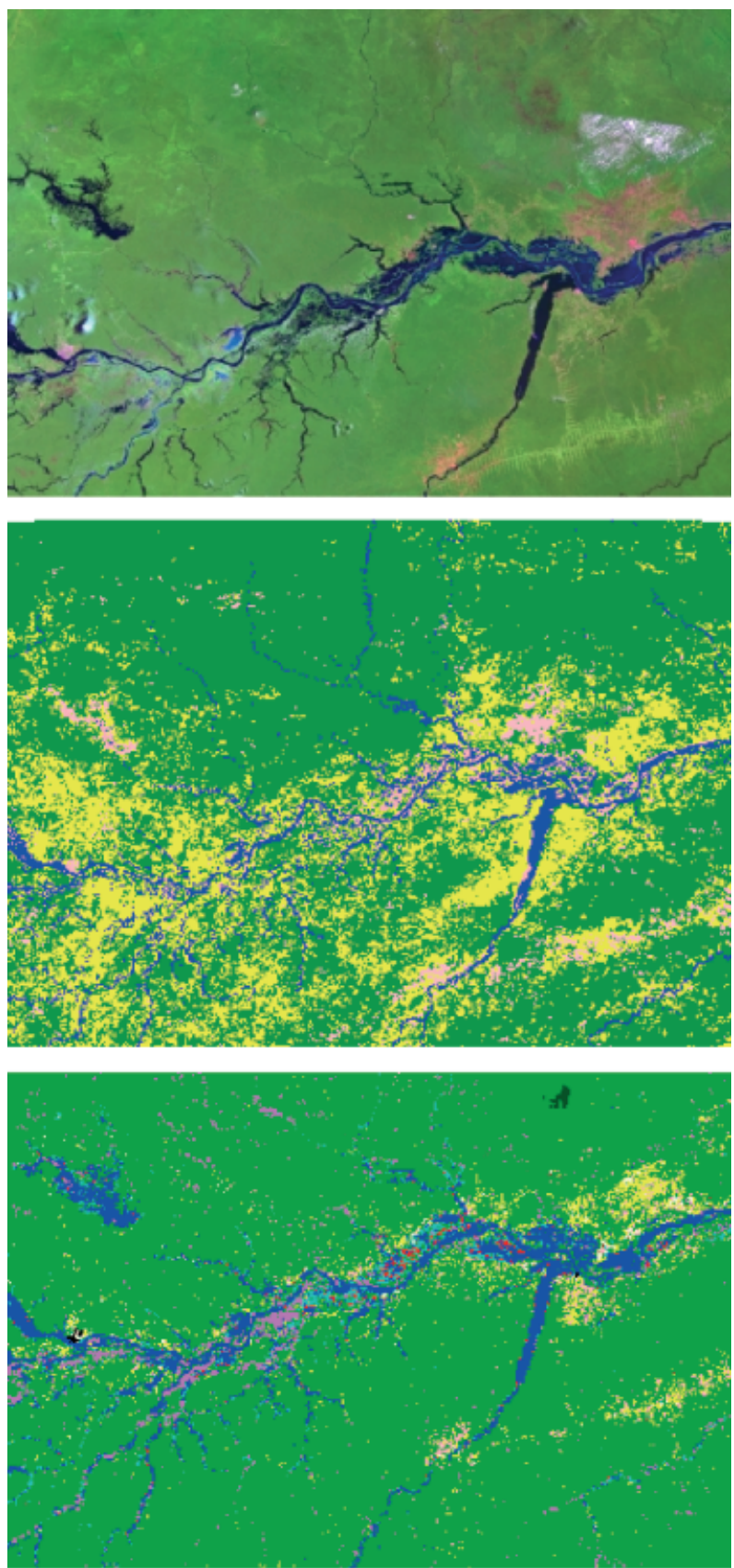

Fig. 3 Top: a false colour composite mosaic of thematic mapper scenes of the Amazon basin $800 \mathrm{~km}$ by $600 \mathrm{~km}$ (Embrapa, 2000). Manaus and the Balbina dam are to the west of the image. The forest appears as green, degraded forest and agriculture appear as light green and red. Middle: The IGBP DISCover Version 1 map of the region. Forest in green, degraded forest and agricultural mosaics in yellow. Bottom: the new South America map of the same region. Forest in green, degraded forest and agricultural mosaics in yellow. Flooded forests are in mauve.

South America map so as to produce a regression line between the area derived from the validation sites and that of the map. A confusion matrix was produced so as to give a breakdown of the percentages of each reference class found in the map class. This helps us to determine the strengths and weaknesses of the class labels.

\section{Results \\ Products}

The map of South America has been produced with 10 major ecological groups (Table 1); humid tropical forests, dry tropical forests, flooded tropical forests, temperate forests, grasslands and shrublands, steppe vegetation, agricultural classes, urban, water and barren classes. It is further divided by seasonality, flooding regime and proportional cover (dense and sparse). Altitudinal zones; lowland, premontane and montane further divide the forest classes as described above. A predominant feature of the classification has been the identification of wetlands; mangroves, seasonally and permanently flooded forests, swamps, seasonally flooded shrub and grasslands. The map is presented in Fig. 4, and is available, along with explicative notes from the Joint Research Centre. For display purposes the map is presented at the level 1 class stage along with the montane forests. For each $1 \mathrm{~km}$ grid on the map we have ancillary data sets on cloud frequency (Fig. 5), albedo, length of growing season, maximum and minimum fractional cover (Figs 1 and 2). The minimum and maximum extents of flooding, ice and snow cover are also available. In Fig. 6 we demonstrate the extent of flooding and changes in spectral reflectance that occur between summer and winter around the Araguaia River in Brazil.

\section{Validation of the thematic content}

The classes in the TREES validation data set comprise of forest $(63 \%)$, agriculture (13\%), grasslands (10\%), mosaics (7\%), wood and shrublands (5\%) and bare soil $(2 \%)$. With the exception of the humid forests and the agricultural mosaics, the classes are poorly represented in the validation sites in comparison with their continental distributions (forests $45 \%$, agriculture $11 \%$, mosaics $12 \%$, grasslands $20 \%$, shrublands $11 \%$ (Table 1 ).

The composition of the map classes as defined by the reference data (Table 3) shows that forests, bare soil, urban and water classes are relatively 'pure', with over $66 \%$ of the class composed of a single reference class. The other classes are composite; however, their class labels are accurate. The mosaic of agriculture and degraded forest consists of forests (39\%), agriculture (35\%) and agricultural mosaics (21\%). While the mosaic of agriculture and degraded vegetation consists of agriculture (29\%) 


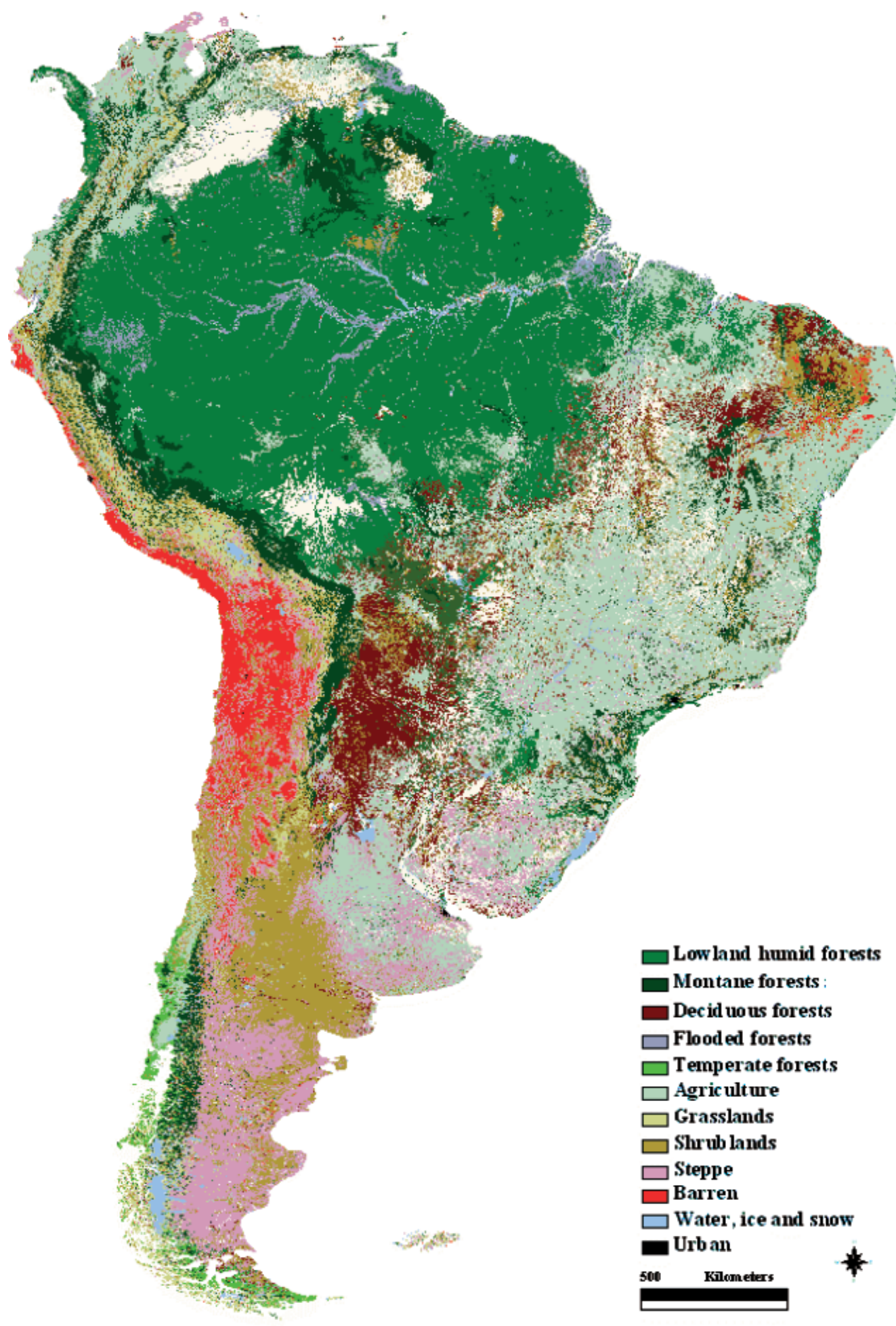

Fig. 4 The South America map displayed at the level 1 generalization (Table 1), with the montane forests above $500 \mathrm{~m}$ shown.

wood and shrubland (21\%) and grassland (25\%). Agriculture consists of 57\% agriculture and 18\% agricultural mosaics. These composite classes reflect the nature of the fragmentation of the landscape into a number of classes at the $1 \mathrm{~km}$ level in this domain. This occurs as these land cover classes exist either at an ecological interface, or, in the case of agriculture and mosaics, as fragmented intrusions along roads. Hence, 
the spatial differences between the $1 \mathrm{~km}$ map and the $30 \mathrm{~m}$ interpretations become more critical. At the continental level, large blocks of such land covers do exist, and therefore should be sampled in the final validation exercise. For the purposes of regression analysis we have therefore aggregated the validation classes into forests, natural non-forest vegetation (grass-

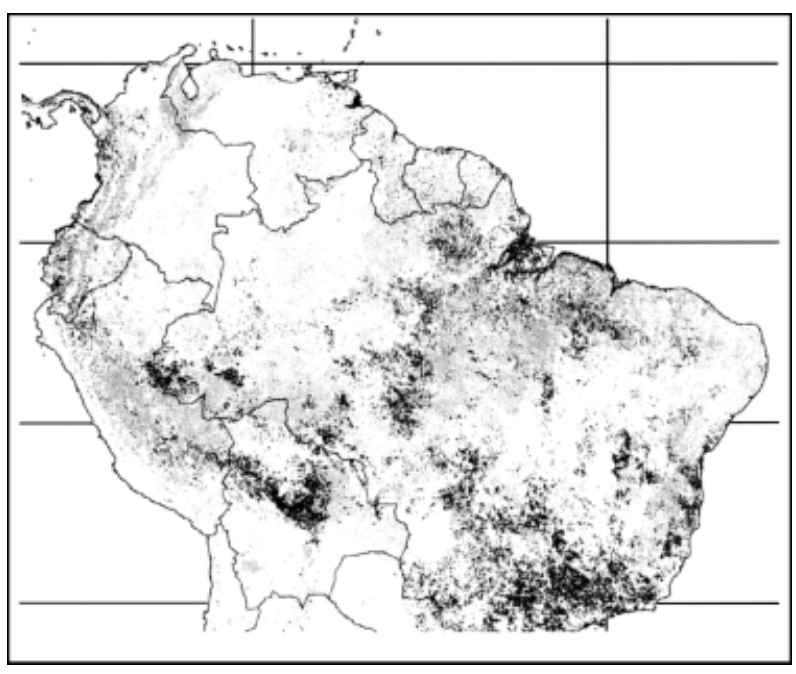

Fig. 5 Cloud persistence at satellite overpass time for February 2000, grey indicates between 10 and 20 days of cloud, areas in black more than 20 days of cloud. The product is available at a daily resolution.

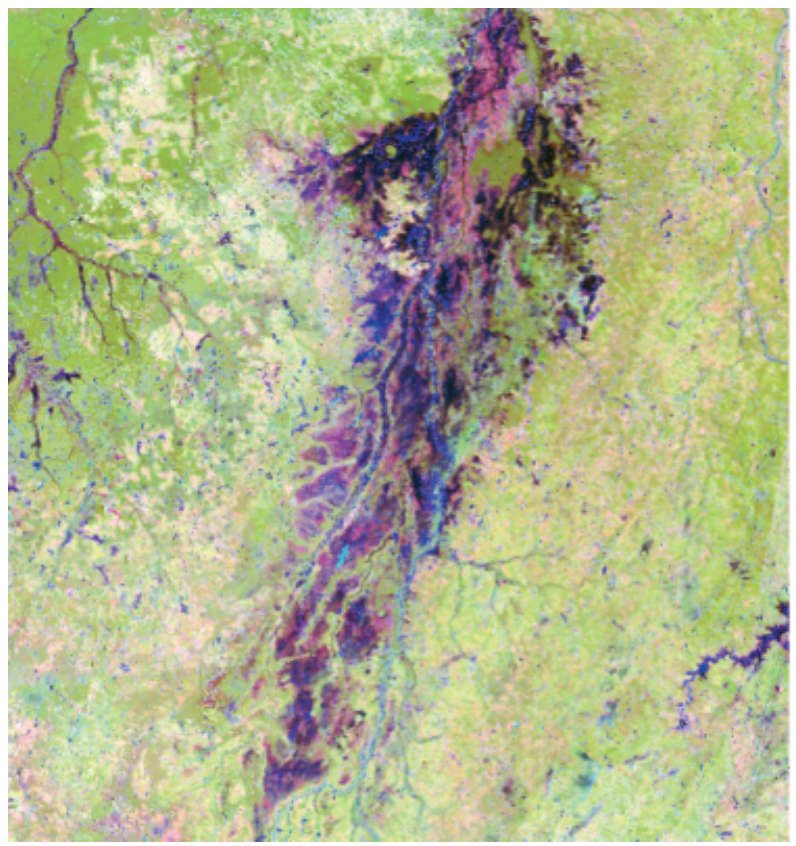

lands and shrublands) and agriculture (intensive and mosaics).

For these aggregated classes, the forest class derived from the map shows an acceptable correlation $\left(r^{2}=0.97\right)$ with the reference data. The nature of the correlation is shown in Fig. 7. The relationships obtained for the other aggregated classes are lower, natural non-forest vegetation $r^{2}=0.59$ and agriculture $r^{2}=0.89$. The aggregation of classes undoubtedly improves the correlation between the data sets, but until a wider geographic validation is undertaken, this is required to overcome the fragmentation issue.

\section{Discussion of results}

\section{The dynamics of South American land cover}

While our map is a static land cover product, access to archived satellite data and to the published literature, enables us to qualitatively highlight some of the important land cover changes occurring in South America. Most striking is the human impact on the continent, with exceptions in the desertic and steppe regions. Foremost among these is the continued advance of the agricultural frontier into the humid forest domain, both from the west along the Andes foothills and from the southeast. The southeast corner of the Brazilian Amazon shows increasing fragmentation,

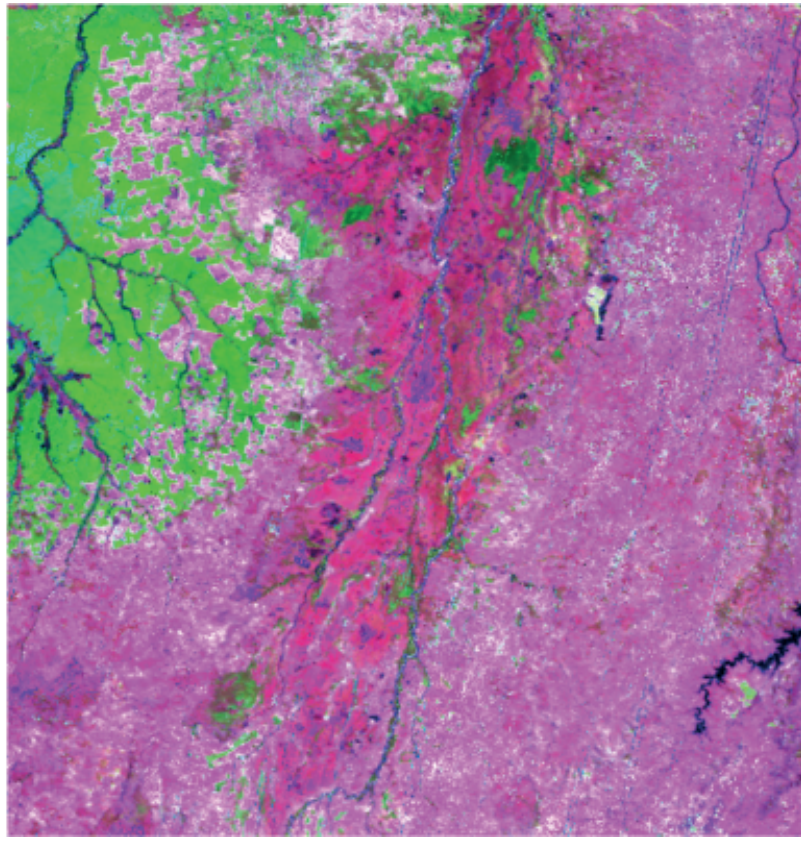

Fig. 6 SPOT VGT composites (SWIR-NIR-Red) of the wet (left) and dry (right) season images of the Araguaia River (centre of the images) and the Xingo River (left of the images). Each imagette is $500 \mathrm{~km}$ in width. Note the extent of the flooding on the Araguaia River (left) and the large change in reflectance of the agricultural zones east and west of the river. The green area around the Xingo is dense tropical forest. 
Table 3 The composition of the map classes as determined by the reference data (columns add up vertically to $100 \%$ )

\begin{tabular}{|c|c|c|c|c|c|c|c|c|c|c|}
\hline & \multicolumn{10}{|c|}{ Map data } \\
\hline & $\begin{array}{l}\text { Forests } \\
(\%)\end{array}$ & $\begin{array}{l}\text { Shrublands } \\
(\%)\end{array}$ & $\begin{array}{l}\text { Grasslands } \\
(\%)\end{array}$ & $\begin{array}{l}\text { Sparse } \\
\text { grasslands (\%) }\end{array}$ & $\begin{array}{l}\text { Agriculture } \\
(\%)\end{array}$ & $\begin{array}{l}\text { Mosaic1 } \\
(\%)\end{array}$ & $\begin{array}{l}\text { Mosaic2 } \\
(\%)\end{array}$ & $\begin{array}{l}\text { Bare } \\
(\%)\end{array}$ & $\begin{array}{l}\text { Urban } \\
(\%)\end{array}$ & $\begin{array}{l}\text { Water } \\
(\%)\end{array}$ \\
\hline \multicolumn{11}{|l|}{ Reference data } \\
\hline Forest & 83 & 17 & 13 & 7 & 17 & 39 & 14 & 6 & 0 & 11 \\
\hline $\begin{array}{l}\text { Woodland and } \\
\text { Shrubland }\end{array}$ & 3 & 17 & 7 & 19 & 5 & 5 & 21 & 5 & 1 & 1 \\
\hline Grassland & 3 & 40 & 60 & 25 & 2 & 1 & 25 & 11 & 3 & 5 \\
\hline Agriculture & 6 & 9 & 8 & 9 & 57 & 35 & 29 & 2 & 19 & 2 \\
\hline Bare & 0 & 5 & 4 & 34 & 1 & 0 & 4 & 72 & 68 & 2 \\
\hline Mosaic & 4 & 11 & 5 & 6 & 18 & 21 & 7 & 1 & 3 & 1 \\
\hline \multirow[t]{2}{*}{ Water } & 1 & 1 & 4 & 0 & 0 & 0 & 0 & 2 & 6 & 78 \\
\hline & 100 & 100 & 100 & 100 & 100 & 100 & 100 & 100 & 100 & 100 \\
\hline
\end{tabular}

The grey shading shows the major contributions of each class. Mosaic 1 is agriculture and degraded forest, Mosaic 2 is agriculture and degraded natural non-forest vegetation.

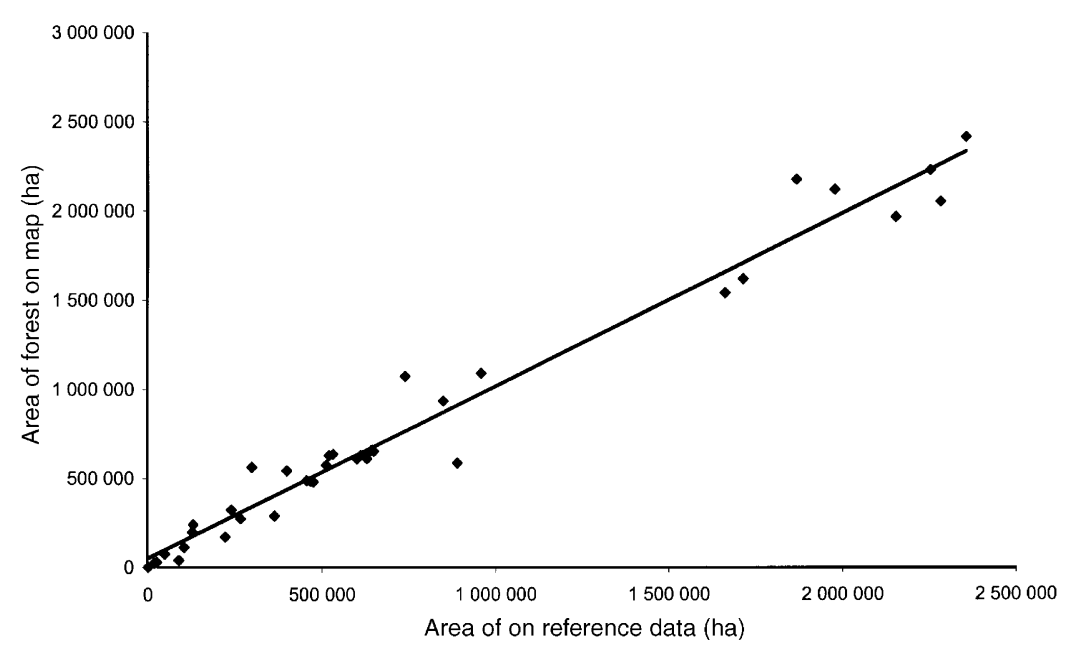

Fig. 7 Relationship between area of humid forest on map and that detected on 40 high-resolution satellite scenes.

and the expansion of anthropogenic activity is clear even compared with the TREES 1992 map (Eva et al., 1999). Notable too is the isolation and fragmentation of remaining natural vegetation in the Brazilian cerrado and caatingas and in the Argentine pampas. The chaco dry forests in southern Bolivia and northern Argentina show increasing numbers of large exploitations, notably around Santa Cruz de la Sierra. To the north of the humid forest domain, the agricultural frontier has expanded in the Venezuelan llanos when compared with Huber's 1988 map. The spatially finer ecosystems along the Andes are more difficult to assess at the scale of the South America map. Nevertheless, our database serves as a first pass stratification for highlighting major changes.

\section{Applications of such maps}

The new land cover map of South America has high scientific relevance in that it documents the current status of the continent in a global context. Not only do we document the land cover types (a breakdown of the area occupied by each major land cover class is shown in Table 1) but we describe the seasonality, percentage vegetation cover, cloud frequency, albedo, and the extent of flooding, snow and ice on the continent. These data can serve as an input to continental climate models and can serve as a database for modelling land cover change scenarios on local and regional climate, for example, replacing humid forest by mixed agriculture. An application is already found in highlighting 
land cover change, and while such maps are inappropriate for making statistical measurements of land cover changes, they highlight 'hotspot' strata for the basis of further measurement by finer spatial resolution satellite data (Achard et al., 2002). Indeed, the parameterization of each land cover type's seasonal cycle and characteristic albedo, facilitates the automatic detection of potential land cover changes. By documenting the distribution and frequency of clouds, flooding, ice and snow for the year 2000 we provide a basis for longer term studies on climate and the hydrological cycle. The finer spatial accuracy of the map enables botanists to put their floristic collections in a wider geographic context than was previously available with the generalized continental maps. The potential impact of vegetation fires on the global climate has long been known (Sieler \& Crutzen, 1980) but always difficult to quantify. Our map of land cover is accompanied by a burnt area product from the same SPOT VGT data and the same period, the year 2000. While problems relating to biomass estimations and burning efficiency remain, three of the main parameters are now available, vegetation type and cover and burnt area. Lastly, in giving a continental overview, the map can help to set priorities for conservation, showing the distribution of ecosystems and highlighting where they are under threat.

The resulting data set for South American has the following characteristics: an up-to-date view of the land cover in a dynamic region; a synoptic view, achieved by the same methods (unlike national maps); a view that fits into a global perspective; a higher spatial accuracy and precision than conventional maps; available in digital format through the internet, which can be easily updated; readily integrated into Geographic Information Systems; a legend applicable to South America land cover types but which fits into the global perspective; accompanied by set of biogeophysical parameters that give valuable ancillary information, for example, seasonality.

As the capacity to produce near-real-time satellite data at finer spatial resolution increases, we can envisage more accurate spatial and thematic maps to document the Earth's surface and its biophysical properties. In a period of rapid land cover change and concerns over climate, the importance of documenting today's land cover need not be stated. This new South America map, in the framework of the GLC 2000 project, is a contribution to that goal.

\section{Acknowledgements}

The authors would like to acknowledge the financial support of the European Commission and of EMBRAPA-CNPM. The
European Space Agency (ESA) is thanked for access to its near-real-time ATSR service. The Rutherford Appleton Laboratories are thanked for technical support. CIRAD of Cayenne and CoroLab Humboldt, Caracas, are thanked for financing and facilitating field missions. The VEGETATION data used in the framework of this project have been provided by VEGA (2000), an initiative cosponsored by the French Space Agency, CNES, the Flemish Institute for Technological Research (VITO, Belgium) and the Joint Research Centre.

\section{References}

Achard F, Estreguil C (1995) Forest classification of Southeast Asia using NOAA AVHRR data. Remote Sensing of the Environment, 54, 198-208.

Achard F, Eva HD, Stibig HJ et al. (2002) Determination of deforestation rates of the world's humid tropical forests. Science, 297, 999-1003.

Adamoli J, Sennhauser E, Acero JM et al. (1990) Stress and disturbance, vegetation dynamics in the dry Chaco region of Argentina. Journal of Biogeography, 17, 491-500.

Adis J (1984) Seasonal igapó forests of Central Amazonian blackwater rivers and their terrestrial arthropod fauna. In: Amazon. Limnology and Landscape Ecology of a Mighty Tropical River and its Basin (ed. Sioli H), pp. 245-267. Dordrecht, Junk.

APN (1999) Eco-regions de la Argentina (Administración de Parques Nacionales, Buenos Aires.

Armesto J, Rozzi R, Smith-Ramírez C et al. (1998) Conservation targets in South American temperate forests. Science, 282, 1271-1272.

Ball GH, Hall DJ (1965) ISODATA, a Novel Method of Data Analysis and Pattern Classification. Technical Report. Stanford Research Institute, Menlo Park, CA.

Balslev H, Luteyn JL (1992) Paramo - An Andean Ecosytem Under Human Influence. Academic Press, London.

Barbosa A (1996) Sistema biogeográfico do cerrado (Universidade Católica de Goiás, Goiânia.

Bartholomé E, Belward AS, Achard F et al. (2002a) GLC 2000 Global Land Cover mapping for the year 2000 - Project status November 2002, EUR 20524 EN. Publication of the European Commission, JRC, Ispra.

Bartholomé E, Bogaert P, Cherlet M et al. (2002b) Rescaling NDVI for the VEGETATION instrument in to apparent fractional cover for dryland studies, GLC 2000 First Results Workshop, Ispra 18-22 March 2002. Joint Research Centre of the European Commission, Ispra. Also available at: http:/ / www.gvm.jrc.it/ glc2000/publications.htm.

Berry PE, Holst BK, Yatskievych K (1995) Flora of the Venezuelan Guayana, Vol. 1. Missouri Botanical Garden, St Louis.

Bliss NB, Olsen LM (1996) Development of a 30-arc-second digital elevation model of South America. In: Pecora Thirteen, Human interactions with the environment perspectives from space, held at Souix Falls, South Dakota, August 20-22, 1996.

Bucher EH (1982) Chaco and caatinga - South American arid savannahs, woodland and thickets. In: Ecology of Tropical Savannahs, Ecological Studies, 42 (eds Huntley BJ, Walker BH), pp. 48-79. Springer-Verlag, New York.

Bullock SH, Mooney HA, Medina E (eds) (1995) Seasonally Dry Tropical Forests. Cambridge University Press, Cambridge. 
Cavelier J, Etter A (1995) Deforestation of montane forests in Colombia as a result of illegal plantations of opium (Papaver somniferum). In: Biodiversity and Conservation of Neotropical Montane Forests - Proceedings (eds Churchill P, Balsev H, Forero E et al.). New York Botanical Garden, New York, pp. 541-550.

Cihlar J, Manak D, D'Iorio M (1994) Evaluation of compositing algorithms for AVHRR data land. IEEE Transactions on Geoscience and Remote Sensing, 32, 427-437.

Clark DB, Clark DA (2000) Landscape-scale variation in forest structure and biomass in a tropical rain forest. Forest Ecology and Management, 137, 185-198.

Conservation International (1992) Coastal Temperate Rain Forests, Ecological Characteristics, Status and Distribution Worldwide. Conservation International, Washington.

D'Souza G, Malingreau JP, Eva HD (1995) Tropical Forest Cover of South and Central America as Derived from Analyses of NOAAAVHRR Data. TREES Series B, Research Report No. 3, European Commission, Luxembourg.

De Granville J-J (1988) Phytogeographical characteristics of the Gianan forests. Taxon, 37, 578-594.

Di Gregorio A, Jansen L (2000) Land Cover Classification System, Classification Concepts and User Manual. Food and Agriculture Organisation of the United Nations, Rome.

Dorman JL, Sellers PJ (1989) A global climatology of Albedo, roughness length and stomatal resistance for atmospheric general circulation models as represented by the simple biosphere model (SiB). Journal of Applied Meteorology, 9, 833-855.

Ducke A, Black GA (1953) Phytogeographical notes on the Brazilian Amazon. Anais da Academia Brasileira de Ciências, 25, $1-46$.

Eiten G (1968) Vegetation forms, Boletim do Instituto de Botânica \#4. Instituto de Botânica, São Paulo.

Eiten G (1982) Brazilian 'savannas'. In: Ecology of Tropical Savannahs, Ecological Studies, 42 (eds Huntley BJ, Walker BH), pp. 25-47. Springer-Verlag, New York.

Elvidge CD, Baugh KE, Dietz JB et al. (1999) Radiance calibration of DMSP-OLS low-light imaging data of human settlements. Remote Sensing of the Environment, 68, 77-88.

Elvidge CD, Baugh KE, Kihn EA et al. (1997) Mapping city lights with nighttime data from the DMSP Operational Linescan System. Photogrammetric Engineering and Remote Sensing, 63, 727-730.

Embrapa (2000) Brasil visto do Espaço, CDROM Embrapa Monitoramento por Satélite - CNPM, Campinas, Brazil. Also available at: http:/ /www.cdbrasil.cnpm.embrapa.br/

Eva HD, Glinni A, Janvier P et al. (1999) Vegetation Map of Tropical South America, Scale 1/5M, TREES Publications Series D, No. 2, EUR EN 18658, European Commission, Luxembourg.

Eva HD, Lambin EF (1998) Burnt area mapping in Central Africa using ATSR data. International Journal of Remote Sensing, 19, 3473-3497.

Friedl M, McIver D, Hodges J et al. (2002) Global land cover mapping from MODIS: algorithms and early results. Remote Sensing of Environment, 83, 287-302.

Gentry A (1990) Four Neo-Tropical Rainforests. Yale University Press, New Haven.

Gentry A (1995) Diversity and floristic composition of neotropical dry forests. In: Seasonally Dry Tropical Forests (eds Bullock
SH, Mooney H, Medina E), pp. 146-194. Cambridge University Press, Cambridge.

Grégoire J-M, Tansey K, Silva J (2003) The GBA 2000 initiative: developing a global burned area database from SPOTVEGETATION imagery. International Journal of Remote Sensing, 24, 1369-1376.

Guerschman JP, Paruelo JM, Di Bella C et al. (2003) Land cover classification in Argentine Pampas using multitemporal landsat TM data. International Journal of Remote Sensing, 24, 3381-3402.

Gutman G, Ignatov A (1998) Derivation of green vegetation fraction from NOAA/AVHRR for use in numerical weather prediction models. International Journal of Remote Sensing, 19, 1533-1543.

Guyot G, Dupont O, Joannes H et al. (1985) Investigation into the mid IR spectral band best suited to monitoring vegetation water content. In: Proceedings of the 18th International ERIM Symposium, Paris. pp. 1049-1063.

Haber WA, Bello E, Zuchowski W (2000) An Introduction to Cloud Forest Trees - Monteverde, Costa Rica, 2nd edn. Mountain Gem Publications, Costa Rica.

Harcourt CS, Sayer JA (1996) The Conservation Atlas of Tropical Forests, the Americas. Simon and Schuster, New York.

Holdridge LR, Grenke WC, Hatheway WH et al. (1971) Forest Environment in Tropical Life Zones. Pergamon Press, Oxford.

Huber O (1988a) Shrublands of the Venezuelan Guayana. In: Tropical Forests (eds Holm-Nielsen LB, Nielsen IC, Balslev H), pp. 271-285. Academic Press, London.

Huber O (1988b) Guayana highlands vs. Guayana lowlands, a reappraisal. Taxon, 37, 595-614.

Huber O (1995) Venezuelan Guayana vegetation map. CVGDELCA/Missouri Botanical Garden, Caracas.

Huber O, Alarcón C (1988) Mapa de vegetación de Venezuela, Ministerio del Ambiente y de los Recursos Naturales Renovables, Caracas.

Huber O, Gharbarran G, Funk V (1995) Vegetation map of Guyana. University of Guyana, Georgetown.

Huber O, Febres G (2001) Ecological Guide to the Gran Sabana. The Nature Conservancy, Arlington.

Hueck K, Seibert P (1972) Vegetationskarte von Südamerika/Mapa de la Vegetación de America del Sur. Fischer, Stuttgart.

IBGE (1992) Manual técnico da vegetação Brasileira, manuais técnicos em geociências no. 1. Fundação Instituto Brasileiro de Geografia e Estatística, Rio de Janeiro.

IGAC (1987) Mapa de uso actual de la tierra. Instituto Geográfico Agustín Codazzi, Bogota.

INRENA (1996) Guia Explicativa del Mapa Forestal (1995). Instituto Nacional de Recursus Naturales, Lima.

Junk WJ (1989) Flood tolerance and tree distribution in Amazonian floodplains. In: Tropical Forests (eds Holm-Nielsen LB, Nielsen IC, Balslev H), pp. 47-64. Academic Press, London.

León RJC, Bran D, Collantes MB et al. (1998) Grandes unidades de vegetación de la Patagonia extra-andina. Ecologia Austral, 8, 126-141.

Lescure J-P, Tostain O (1989) Les Mangroves guyanaises. Bois et Forêts des tropiques, 2, 35-42.

Loveland TR, Zhu Z, Ohlen DO et al. (1999) An analysis of the IGBP global land-cover characterization process. Photogrammetric Engineering and Remote Sensing, 65, 1021-1032. 
Marengo J (1992) Interannual variability of surface climate in the Amazon basin. International Journal of Climatology, 12, 853-863.

Mayaux P, Janodet E, Blair-Myers C et al. (1997) Vegetation Map of Central Africa at 1.5M. TREES Publications Series D1, EUR 17322. European Commission, Luxembourg.

MDSMA (1995) Mapa forestal de Bolivia 1,1 000 000. Ministerio de desarrollo sostenible y medio ambiente, La Paz.

Neira E, Verscheure H, Revenga C (2002) Chile's Frontier Forests, Conserving a Global Treasure. Global Forest Watch, WRI, Washington.

Nobre CA, Sellers PJ, Shukla J (1991) Amazonian de-forestation and regional climate change. Journal of Climate, 4, 957-988.

Oliveira A, Nelson B (2001) Floristic relationship of terra firme forests in the Brazilian Amazon. Forest Ecology and Management, 146, 169-179.

Parker TA, Gentry AH, Foster RB et al. (1993) The lowland dry forests of Santa Cruz, Bolivia, a global conservation priority. RAP (Rapid Assessment Program) Working Papers 4, Conservation International, Washington, DC.

Paruelo JM, Jobbágy EG, Sala OE (1998) Biozones of Patagonia (Argentina). Ecologia Austral, 8, 145-153.

Pires JM, Prance GT (1985) The vegetation types of the Brazilian Amazon. In: Key Environments Amazonia (eds Prance GT, Lovejoy TE), pp. 109-145. Pergamon Press, Oxford.

Pounds JA, Fogden MPL, Campbell JH (1999) Biological response to climate change on a tropical mountain. Nature, 398, 611-615.

RADAMBRAZIL (1973-1978) Levamento de recursos naturais. Ministério das minas e energia, Departamento nacional da produção mineral, Rio de Janeiro.

Ratter JA (1992) Transitions between the cerrado and the forest vegetation in Brazil. In: Nature and Dynamics of Forest-Savanna Boundaries (eds Furley PA, Proctor J, Ratter JA), pp. 417-429. Chapman and Hall, London.

Rosenqvist $\AA$ (1996) The global rain forest mapping project by JERS-1 SAR. International Archives of Photogrammetry and Remote Sensing, 13, 594-598.

Rosenfeld D (1999) TRMM observed first direct evidence of smoke from forest fires inhibiting rainfall. Geophysical Research Letters, 26, 3105-3108.

Rosenqvist $\AA$, Forsberg BR, Pimentel T et al. (1998) Using JERS-1 L-band SAR to estimate methane emissions from the Jaú River floodplain (Amazon/Brazil). Proceedings of the International Geoscience and Remote Sensing Symposium (IGARSS '98), Seattle, USA, 1998, 6-10 July 1998. Vol. III, pp. 1623-1625.

Rosenzweig C, Hillel D (1998) Climate Change and the Global Harvest; Potential Impacts of the Greenhouse Effect on Agriculture. Oxford University Press, Oxford.

Sampaio EVSB (1995) Overview of the Brazilian caatinga. In: Seasonally Dry Tropical Forests (eds Bullock SH, Mooney HA,
Medina E), pp. 35-58. Cambridge University Press, Cambridge.

Sarmiento G (1984) The ecology of neotropical savannas. Harvard University Press, Cambridge, MA, USA.

Scepan J (1999) Thematic validation of high-resolution global land-cover data sets. Photogrammetric Engineering and Remote Sensing, 65, 1051-1060.

Sellers PJ, Dickinson RE, Randall DA et al. (1997) Modeling the exchanges of energy, water, and carbon between continents and the atmosphere. Science, 275, 502-509.

Shukla J, Nobre CA, Sellers PJ (1990) Amazon deforestation and climate change. Science, 247, 1322-1325.

Seiler W, Crutzen PJ (1980) Estimates of gross and net fluxes of carbon between the biosphere and the atmosphere from biomass burning. Climate Change, 2, 207-247.

Sierra R (1999) Vegetacion Remanente del Ecuador Continental. Scale 1:1.000.000. Proyecto INEFAN/GEF-BIRF, Wildlife Conservation Society and EcoCiencia, Quito.

Soriano A (1993) Rio de la Plata grasslands. In: Natural grasslands. Introduction and Western Hemisphere. Series Ecosystems of the World (ed. Coupland RT), pp. 367-408. Elsevier, Amsterdam.

Spichiger R, Ramella L (1988) The forests of the Paraguayan Chaco. In: Tropical Forests (eds Holm-Nielsen LB, Nielsen IC, Balslev H), pp. 259-270. Academic Press, London.

Stadtmüller T (1987) Cloud Forests in the Humid Tropics - a Bioligraphical Review. The United Nations University, Costa Rica.

Stone TA, Schlesinger P, Woodwell GM et al. (1994) A map of the vegetation of South America based on satellite imagery. Photogrammetric Engineering and Remote Sensing, 60, 441-451.

ter Steege H (2001) National Vegetation Map of Guyana. Guyana Forestry Commission, Georgetown.

Tilman D, Fargione J, Wolff B et al. (2001) Forecasting agriculturally driven global environmental change. Science, 292, 281284.

UNESCO (1981) Carte de la Végétation d'Amérique du Sud. UNESCO, Paris.

United Nations (2001) World Population Prospects. The 2000 Revision Highlights. UN Population Division, Department of Economic and Social Affairs, New York.

United Nations Environment Programme (1999) GEO-2000, Global Environmental Outlook. Earthscan Publications Ltd., London.

Van Dijk A, Callis SL, Sakamoto CM et al. (1987) Smoothing vegetation index profiles: an alternative method for reducing radiometric disturbances in NOAA/AVHRR data. Photogrammetric Engineering and Remote Sensing, 53, 1059-1067.

Veblen TT, Donoso C, Kitzberger T et al. (1996) Ecology of Southern Chilean and Argentinean Nothofagus forests. In: The Ecology and Biogeography of Nothofagus forests (eds Veblen TT, Hill RS, Read J), pp. 293-353. Yale University Press, New Haven. 